\title{
Physical, Physiological and Sanitary Quality of Canola Seeds After the Application of Maturing Herbicides
}

Thalita Pedrozo Pilla

Dept. of Agronomy, The Federal University of Fronteira Sul - UFFS, Campus Erechim ZIP CODE: 99700-000, Erechim, Rio Grande do Sul, Brazil Tel: +55-54-99710-4860Ｅ-mail: thali_pp@hotmail.com

\section{Leandro Galon (Corresponding author)}

Dept. of Agronomy, The Federal University of Fronteira Sul - UFFS, Campus Erechim ZIP CODE: 99700-000, Erechim, Rio Grande do Sul, Brazil

Tel: +55-54-99698-5955Ｅ-mail: leandro.galone@gmail.com

Daiani Brandler

Dept. of Agronomy, The Federal University of Fronteira Sul - UFFS, Campus Erechim ZIP CODE: 99700-000, Erechim, Rio Grande do Sul, Brazil Tel: +55-54-99648-6441Ｅ-mail: daianibrandler@hotmail.com

\section{Felipe Bianchessi}

Dept. of Agronomy, The Federal University of Fronteira Sul - UFFS, Campus Erechim ZIP CODE: 99700-000, Erechim, Rio Grande do Sul, Brazil Tel: +55-54-99637-6336_E-mail: felipbianchessi@hotmail.com

Rodrigo José Tonin

Dept. of Agronomy, The Federal University of Fronteira Sul - UFFS, Campus Erechim ZIP CODE: 99700-000, Erechim, Rio Grande do Sul, Brazil Tel: +55-54-99924-6052Ｅ-mail: tonin_rodrigo@hotmail.com 
Josiel Ricardo Toni

Dept. of Agronomy, The Federal University of Fronteira Sul - UFFS, Campus Erechim ZIP CODE: 99700-000, Erechim, Rio Grande do Sul, Brazil

Tel: +55-54-99137-1272Ｅ-mail: josielricardotoni@gmail.com

\author{
Cesar Tiago Forte \\ Dept. of Agronomy, The Federal University of Fronteira Sul - UFFS, Campus Erechim \\ ZIP CODE: 99700-000, Erechim, Rio Grande do Sul, Brazil \\ Tel: +55-54-99688-9706_E-mail: cesartiagoforte@hotmail.com
}

\author{
Leandro Vargas \\ Laboratory of Weed, Embrapa Trigo, Passo Fundo \\ ZIP CODE: 99050-970, Passo Fundo, Rio Grande do Sul, Brazil \\ Tel: +55-54-99122-7921Ｅ-mail: leandro.vargas@embrapa.br
}

Received: Mar. 29, 2020 Accepted: May 12, $2020 \quad$ Published: May 21, 2020

doi:10.5296/jas.v8i3.16756

URL: https://doi.org/10.5296/jas.v8i3.16756

\begin{abstract}
The use of herbicides to anticipate harvesting in species with easy seed dehiscence may be an alternative to avoid maturation losses. However, the appropriate time for herbicide application is extremely important as it prevents the seeds from remaining in the field for long periods. The objective of this study was to evaluate the efficiency of the application of maturing herbicides in two distinct seasons, and their effects on the physical, physiological, and sanitary quality of canola seeds. A randomized block experimental design arranged in a factorial scheme (herbicide x season + control) with four replications was used. Hybrid 50 canola plants were matured with the herbicides: glufosinate, paraquat, glyphosate, diquat, saflufenacil, 2,4-D, and paraquat + diuron twice during the crop cycle, G3 and G4, and two controls without application for each epoch, with the first being harvested the day of product application, and the second kept in the field until the final crop cycle. Analyses of one thousand seed weight, electrical conductivity, emergence speed index, and a sanity test were performed. The application of maturing herbicides to canola increases the one thousand seed weight and rate of emergence speed. At the same time, it increases electrical conductivity and the incidence of fungi. Plants that remained in the field until the end of the crop cycle and did not receive herbicide
\end{abstract}


application resulted in higher quality seeds. The most appropriate moment to apply maturation herbicides to canola is in the G4 season.

Keywords: Brassica napus L. var. oleifera, anticipation of harvest, seed quality

\section{Introduction}

Canola (Brassica napus L. var. oleifera) is one of the most important crops in the world, mainly due to the potential for extracting oil from its seeds that has high economic and industrial value, being used for human consumption and also as raw material for the production of biodiesel. In addition, canola meal is used as a protein source in animal feed. Thus, canola cultivation is one of the most profitable, as well as important alternatives for winter cultivation (Tomm et al., 2009).

However, one of the most frequent problems that growers face after implantation of this crop is the high losses in the harvest from uneven plant maturity and canola silicon (canola fruit, which varies in length, shape and color for each cultivar) dehiscence, which limit performance and present important challenges for the expansion of production (Neves, 2005). In this sense, the choice of the appropriate season for seed harvesting is one of the most important factors for obtaining high yields (Franco et al., 2013).

Harvesting at the appropriate time, as close as possible to physiological maturity, is essential for the preservation of seed quality. However, in order to anticipate harvesting, it is necessary to use techniques that favor this procedure, as the closer to physiological maturity, the higher the water content of the seeds, and the plants have a large number of branches and green leaves, aspects that make harvesting unfeasible (Coelho et al., 2007).

The use of maturing herbicides results in the rapid drying of all parts of the plant, allowing the harvest to be carried out in advance (Botelho et al., 2016; Kappes et al., 2012), as the seeds will reach the humidity indicated for harvesting in a shorter interval of time compared with those that experience water loss naturally. When applied properly, herbicides promote uniform maturation of plants, allow harvesting, reducing yield losses and also maintaining the physical, physiological, and sanitary quality of the seeds (Lamego et al., 2013).

However, several aspects should be considered, among them, the correct timing of herbicide application, mode of action and dose used, and the possibility of product residues in the seeds (Lacerda et al., 2005; Kappes et al., 2009). These factors may compromise seed quality and, consequently, crop productivity (Franco et al., 2013).

The use of herbicides for maturation in order to hasten harvesting has been studied in various crops, such as soybean (Pelúzio et al., 2008; Kappes et al., 2009; Daltro et al., 2010; Marcandalli et al., 2011; Botelho et al., 2016), beans (Kamikoga et al., 2009; Coelho et al., 2012; Kappes et al., 2012; Pinto et al., 2014), and wheat (Bellé et al., 2014). However, there are few studies regarding the use of maturing herbicides to hasten harvesting in canola crops.

The hypothesis of this study is that the applied herbicides differ in relation to their efficiency concerning the physical, physiological, and sanitary quality of canola seeds, and that applications at times closer to the physiological maturity of the crop cycle are the most appropriate. 


\section{Ml Macrothink}

Journal of Agricultural Studies

ISSN 2166-0379

2020, Vol. 8, No. 3

The objective of this work was to study the efficiency of the application of maturing herbicides at two different times and their effects on the physical, physiological, and sanitary quality of canola seeds.

\section{Material and Methods}

This research was carried out in two stages, both at the Federal University of Fronteira Sul (UFFS), Erechim/RS. The first phase consisted of the installation of the experiment and application of the field treatments conducted in the experimental area, and the second phase was characterized by the physical, physiological, and sanitary analysis carried out in the Laboratory of Sustainable Management of Agricultural Systems during 2017 and 2018.

The area used for canola sowing was previously managed with the herbicide glyphosate, at a dose of $1080 \mathrm{~g} \mathrm{ha}^{-1}$ of acid equivalent, to eliminate existing vegetation.

Correction of soil fertility was carried out along with canola sowing, and according to the physical-chemical analysis, followed by the technical recommendations for the crop (Rolas, 2016), using $350 \mathrm{~kg} \mathrm{ha}^{-1}$ of fertilizer with the formulation 05-20-20 (NPK).

Each experimental unit (parcel) consisted of an area of $15 \mathrm{~m}^{2}(5 \mathrm{~m} \times 3 \mathrm{~m})$, with sowing performed in the no-tillage system on 06/14/2017, using a six-row seeder/fertilizer with $0,5 \mathrm{~m}$ between rows, depth of $1-2 \mathrm{~cm}$ and density of 50 plants $\mathrm{m}^{-2}$.

The experimental design used randomized blocks arranged in a $7 \times 2+2$ factorial scheme, with four replications. In factor $\mathrm{A}$, the herbicides (ammonium glufosinate, paraquat, glyphosate, diquat, saflufenacil, 2,4-D, and paraquat + diuron) were allocated as described in Table 1. In factor B, the canola Hyola 50, with its two drying seasons (G3 - when the first ten main stem cells are more than $4 \mathrm{~cm}$ wide, and G4 - when the first ten main stem cells begin to mature) (Cordeiro et al., 1999), in addition to two unapplied controls, where one was collected on the day of application of the products and the second kept in the field until the final cycle for later harvest.

Table 1. Herbicide treatments and their respective doses, used for the maturation of canola, hybrid Hyola 50. UFFS, Erechim, 2019

\begin{tabular}{cccc}
\hline Ingredient active & $\begin{array}{c}\text { Dose } \\
\left(\mathrm{g} \mathrm{ha}^{-1} \text { de i.a or e.a }\right)\end{array}$ & $\begin{array}{c}\text { Commercial } \\
\text { product }\end{array}$ & $\begin{array}{c}\text { Dose } \\
\left(\mathrm{L} \mathrm{kg} \mathrm{ha}^{-1}\right)\end{array}$ \\
\hline Ammonium glufosinate & 400 & Finale & 2,0 \\
Paraquat & 400 & Gramoxone & 2,0 \\
Glyphosate & 1440 & Roundup original & 3,0 \\
Diquat & 400 & Reglone & 2,0 \\
Saflufenacil & 49 & Heat & 0,07 \\
$2,4-\mathrm{D}$ & 806 & DMA 806 BR & 1,0 \\
Paraquat + diuron & $400+200$ & Gramocil & 2,0 \\
\hline
\end{tabular}

The products were applied with a $\mathrm{CO}_{2}$ pressure pressurized precision sprayer equipped with 
four DG 110.02 spray heads, under a constant pressure of $200 \mathrm{kPa}$ and a displacement velocity of $1,0 \mathrm{~m} \mathrm{~s}^{-1}$, with a flow of $150 \mathrm{~L} \mathrm{ha}^{-1}$ of herbicide syrup.

Harvesting of each experimental unit was carried out seven days after herbicide application in each season, and was performed manually using pruning shears, and only the plants of the two central lines of each plot were harvested when $40-60 \%$ of the seeds of the main branch began to change from green to brown, that is, reaching a maximum of $18 \%$ moisture in the field. After harvesting, the plants were packed in paper bags and then subjected to oven drying with forced air circulation and a temperature of $35^{\circ} \mathrm{C}$ until reaching 9-10\% humidity. This same operation was carried out for the controls that were harvested on the same date of application of the maturing herbicides.

The other control treatments were collected when the seeds presented in the field and the water content was approximately $18 \%$, that is, when the crop cycle was completed.

After the drying of all the treatments and the manual threshing of the silicon to obtain the seeds, the second stage of this study started in the Laboratory of Sustainable Management of Agricultural Systems of UFFS, Campus Erechim. For the determination of the physical, physiological, and sanitary quality of the seeds, the following analyses were carried out:

One thousand seed weight: this was performed by counting eight replicates of 100 seeds per treatment, weighed separately in an analytical balance. The mean result was multiplied by ten and expressed in grams (Brasil, 2009).

Electrical conductivity: The seeds were initially subjected to a pre-treatment of disinfestation in $70 \%$ alcohol for 1 minute. Then they were placed in sodium hypochlorite in the concentration of $2.5(\mathrm{v} / \mathrm{v})$, for 15 minutes, being subsequently subjected to rinses in distilled and autoclaved water.Four samples of 50 seeds were used for each treatment. The samples were weighed on a precision scale and then placed in glass beakers containing $50 \mathrm{~mL}$ of distilled water and kept in BOD (Biochemical Oxigen Demand) at $25^{\circ} \mathrm{C}$ for $24 \mathrm{~h}$, according to the method described by AOSA (2002). After this period, the electrical conductivity was determined by reading in a digital conduit meter, DIGIMED, with results expressed in $\mu \mathrm{S} \mathrm{cm}^{-1}$ $\mathrm{g}^{-1}$.

Index of emergence velocity (IVE): this was conducted in a sterile sieved sand substrate (two autoclaves at $120{ }^{\circ} \mathrm{C} \pm 1 \mathrm{~atm}$, with an interval of $24 \mathrm{~h}$ ), with four replicates of 50 seeds per treatment. The evaluations were performed daily by counting the number of seedlings that showed visible cotyledonary leaves. At the end of the test, with the daily data on the number of emerged seedlings, the rate of emergence (IVE) was calculated according to the equation proposed by Maguire (1962):

$\mathrm{IVE}=(\mathrm{G} 1 / \mathrm{N} 1)+(\mathrm{G} 2 / \mathrm{N} 2)+\ldots+(\mathrm{Gn} / \mathrm{Nn})$, wherein:

$\mathrm{IVE}=$ Emergence speed index

$\mathrm{G}=$ number of normal seedlings counted daily

$\mathrm{N}=$ number of days of sowing at $1 \mathrm{st}, 2 \mathrm{nd}$... $\mathrm{n}$ evaluation. 
Sanity test: this involved a blotter test with freezing, using 200 seeds of each treatment, distributed in four replicates of 50 seeds in boxes of the gerbox type, on two sheets of sterilized germitest paper and moistened with distilled water in the ratio of 2.5 times the dry paper weight. The seeds were initially incubated in a germination chamber at $20 \pm 2{ }^{\circ} \mathrm{C}$ and a photoperiod for $12 \mathrm{~h}$ light for $24 \mathrm{~h}$ dark and then transferred to the freezer at $-20{ }^{\circ} \mathrm{C}$ for $24 \mathrm{~h}$. Subsequently, the seeds were again subjected to incubation in a germination chamber at $20 \pm 2{ }^{\circ} \mathrm{C}$ and photoperiod of $12 \mathrm{~h}$ light/ $12 \mathrm{~h}$ dark for five days, and at the end of that period, the incidence of fungi present in the samples was evaluated through stereoscopic and optical microscopy. Fungi were identified at the genus level, according to specialized literature (Henning, 2015).

Data were submitted to analysis of variance by the $\mathrm{F}$ test, and when a significant effect was detected, the variables were compared by the Tukey test $(\mathrm{p}<0.05)$. The analyses were performed using the statistical software Winstat - version 2.11.

\section{Results and Discussion}

Significant interactions were observed for all variables studied in all tested treatments (herbicides $\mathrm{x}$ times). The treatment that was most successful in the one thousand seed weight in the two application times was the additional control, that is, the one that was kept in the field until the end of the cycle, with natural maturation, without the use of herbicides. This result shows that the time of application of the desiccants, the different mechanisms of product actions and even environmental factors tend to influence the quality of the seed (Table 2). On the other hand, comparing the herbicide treatments with each other within each season, it can be noted that diquat and saflufenacil showed the best results in both seasons.

The 2,4-D and paraquat provided inferior results in comparison to the other treatments in the first season of herbicide application. The control, ammonium glufosinate, paraquat, and paraquat + diuron, in the second season of application, showed the lowest values of the one thousand seed weight. The reduction of the one thousand seed weight in the first season of application of the herbicides may be related to a greater humidity at the moment of application. In relation to the treatments, the mode of action of the product, the phenological stage of the crop, and the phytotoxicity caused by the herbicide may have been the cause of the difference in the results for the variable weight of one thousand seeds.

Kamikoga et al. (2009) did not find a significant difference between treatments, when applying different maturing herbicides in a bean culture at 28 and 43 days after flowering, for the one thousand seed weight. However, Santos et al. (2004), when applying carfentrazone-ethyl in the preharvesting of bean, verified that the one thousand seed weight was affected by the application time and also by the herbicide dose, with smaller increments in the higher doses used. The application of paraquat or the mixture of paraquat + diquat on the common bean did not affect the one thousand seed weight (Domingos et al., 2001). 
Table 2. Weight of thousand $(\mathrm{g})$ in Hyola 50 hybrid canola seeds as a function of treatments application and maturation times

\begin{tabular}{cccc}
\hline \multirow{2}{*}{ Treatments } & Dose & \multicolumn{2}{c}{ Time of application } \\
\cline { 3 - 4 } & $\left(\mathrm{g} \mathrm{ha}^{-1} \mathrm{de} \mathrm{i.a}\right.$ or e.a $)$ & $\mathrm{G} 3$ & $\mathrm{G} 4$ \\
\hline Control & --- & $2,85 \mathrm{cdeA}^{1}$ & $2,74 \mathrm{dA}$ \\
Ammonium glufosinate & 400 & $2,82 \mathrm{deA}$ & $2,90 \mathrm{cdA}$ \\
Paraquat & 400 & $2,71 \mathrm{eA}$ & $2,80 \mathrm{cdA}$ \\
Glyphosate & 1440 & $2,94 \mathrm{bcdA}$ & $2,94 \mathrm{bcA}$ \\
Diquat & 400 & $3,01 \mathrm{bcB}$ & $3,10 \mathrm{bA}$ \\
Saflufenacil & 49 & $3,07 \mathrm{bA}$ & $3,11 \mathrm{bA}$ \\
2,4-D & 806 & $2,69 \mathrm{eB}$ & $2,94 \mathrm{bcA}$ \\
Paraquat+diuron & $400+200$ & $2,84 \mathrm{cdeA}$ & $2,90 \mathrm{cdA}$ \\
Testemunha adicional & --- & $4,05 \mathrm{aB}$ & $4,87 \mathrm{aA}$ \\
\hline Average overall & --- & \multicolumn{3}{c}{3,07} \\
CV $(\%)$ & --- & 2,54 & \\
\hline
\end{tabular}

${ }^{1}$ Means followed by the same lowercase letter in the column and upper case in the row do not differ significantly from each other by the Tukey test $(\mathrm{p} \leq 0.05)$.

The values of the weight of one thousand bean seeds increased over the days after sowing and application of diquat herbicide, coinciding with the maturation process of the seeds (Franco et al., 2013). Cechinel (2014), evaluating the effect of maturing herbicides with different active ingredients and mechanisms of action on wheat seed yield, concluded that the one thousand seed weight was not affected by glufosinate ammonium, flumioxazin, and carfentrazone-ethyl and their different doses, but the time of cultivation had an effect on the one thousand seed weight.

It was observed that in the two application times, the additional control presented a lower electrical conductivity value in relation to the other treatments (Table 3), demonstrating, in this case, seeds of greater vigor, as the lower the electrical conductivity, the higher the seed quality. According to Gonzales et al. (2009), the high electrical conductivity results in higher leachate output (cellular constituents) of the seed resulting in deterioration and loss of vigor.

Besides the two controls, the herbicides ammonium glufosinate and paraquat stood out in the first season of application., that is, they resulted in more vigorous seeds, compared to the other treatments with herbicides. In the second period, in addition to the additional control, there was lower electrical conductivity when ammonium glufosinate and saflufenacil were used. On the other hand, it was observed that when the 2,4-D was used, the canola seeds lost their vigor, regardless of the application period, which explains the most pronounced values in the electrical conductivity test. Because it is a systemic herbicide, it may have affected the integrity of the seed membranes. Marcandalli et al. (2011) evaluated the effect of herbicide application on different reproductive stages of soybean, observing that the physiological quality of the seeds obtained after application of glyphosate and paraquat, showed higher values of electrical conductivity, evidencing that they were seeds of lower vigor and quality. 
Table 3. Electrical conductivity $\left(\mu \mathrm{sm}^{-1} \mathrm{~g}^{-1}\right.$ ) in Hyola 50 hybrid canola seeds as a function of treatments and maturation times

\begin{tabular}{cccc}
\hline & Dose & \multicolumn{2}{c}{ Time of application } \\
\cline { 3 - 4 } Treatments & $\left(\mathrm{g} \mathrm{ha}^{-1}\right.$ de i.a or e.a $)$ & $\mathrm{G} 3$ & $\mathrm{G} 4$ \\
\hline Control & --- & $107,82 \mathrm{fgB}^{1}$ & $698,11 \mathrm{cA}$ \\
Ammonium Glufosinate & 400 & $144,78 \mathrm{efB}$ & $305,02 \mathrm{fA}$ \\
Paraquat & 400 & $158,19 \mathrm{eB}$ & $1289,45 \mathrm{bA}$ \\
Glyphosate & 1440 & $237,70 \mathrm{~dB}$ & $443,54 \mathrm{dA}$ \\
Diquat & 400 & $419,58 \mathrm{cB}$ & $669,83 \mathrm{cA}$ \\
Saflufenacil & 49 & $358,68 \mathrm{cA}$ & $318,18 \mathrm{eB}$ \\
2,4-D & 806 & $662,94 \mathrm{aB}$ & $1411,91 \mathrm{aA}$ \\
Paraquat+diuron & $400+200$ & $558,16 \mathrm{bA}$ & $433,32 \mathrm{~dB}$ \\
Testemunha adicional & --- & $95,69 \mathrm{gA}$ & $67,45 \mathrm{gB}$ \\
\hline Average overall & --- & \multicolumn{2}{c}{467,08} \\
CV $(\%)$ & --- & \multicolumn{2}{c}{4,06} \\
\hline
\end{tabular}

${ }^{1}$ Means followed by the same lowercase letter in the column and upper case in the row do not differ significantly from each other by the Tukey test $(\mathrm{p} \leq 0.05)$.

The same situation occurred in the research conducted by Botelho et al. (2016) who, when evaluating the effect of the application of maturing herbicides at different times on the physiological quality of soybean seeds after six months of storage, found that, regardless of the product used, the electrical conductivity values were higher than those of the control, demonstrating that the herbicides may interfere with the integrity of the membranes, directly affecting seed vigor.

The application of paraquat favored the physiological quality of bean seeds when evaluating electrical conductivity, compared with the seeds of plants that did not receive herbicide application (Coelho et al., 2012). In evaluating the effect of application times and herbicides on the productivity and physiological quality of bean seeds, Assis et al. (2019) observed that the ripening herbicides application on the plants positively affected seed vigor in the evaluation of electrical conductivity.

The herbicides paraquat, diquat, and paraquat + diquat had no effect on the electrical conductivity of soybean seeds (Lacerda et al., 2005). Marchiori et al. (2002), applied ammonium glufosinate, carfentrazone-ethyl, paraquat, and diquat to canola crops, and did not verify any effect on the electrical conductivity, which does not corroborate with the present study, with the exception of ammonium glufosinate that presented satisfactory results.

Regarding the rate of emergence (Table 4), regardless of the season of application of the 
products, the use of diquat excelled in relation to the other treatments, resulting in a larger number of seedlings emerging on the substrate. However, the control and 2,4-D herbicide caused the lowest rates of emergence in the two application periods, demonstrating the inefficiency of this product for application to canola plants. When comparing the times between them, it was observed that G4 presented the highest rates of emergence speed in all treatments, and except for the application of ammonium glufosinate, where the use of G3 was better than in the second season of application.

Table 4. Hyola 50 Hybrid canola seed emergence speed index as a function of treatments and maturation times

\begin{tabular}{cccr}
\hline \multirow{2}{*}{ Treatments } & Dose & \multicolumn{2}{c}{ Time of application } \\
\cline { 3 - 4 } & $\left(\mathrm{g} \mathrm{ha}^{-1}\right.$ de i.a or e.a $)$ & $\mathrm{G} 3$ & $\mathrm{G} 4$ \\
\hline Control & --- & $0,00 \mathrm{gB}^{1}$ & $2,31 \mathrm{eA}$ \\
Ammonium Glufosinate & 400 & $18,07 \mathrm{cA}$ & $7,93 \mathrm{~dB}$ \\
Paraquat & 400 & $3,43 \mathrm{efB}$ & $13,04 \mathrm{cA}$ \\
Glyphosate & 1440 & $6,30 \mathrm{deB}$ & $24,31 \mathrm{bA}$ \\
Diquat & 400 & $30,69 \mathrm{aB}$ & $40,04 \mathrm{aA}$ \\
Saflufenacil & 49 & $2,53 \mathrm{fgB}$ & $26,51 \mathrm{bA}$ \\
2,4-D & 806 & $2,90 \mathrm{fgA}$ & $1,07 \mathrm{eA}$ \\
Paraquat+diuron & $400+200$ & $6,82 \mathrm{~dB}$ & $25,21 \mathrm{bA}$ \\
Testemunha adicional & --- & $25,64 \mathrm{bA}$ & $25,32 \mathrm{bA}$ \\
\hline Average overall & --- & \multicolumn{2}{c}{14,56} \\
CV $(\%)$ & --- & \multicolumn{2}{c}{8,96} \\
\hline
\end{tabular}

${ }^{1}$ Means followed by the same lowercase letter in the column and upper case in the row do not differ significantly from each other by the Tukey test $(\mathrm{p} \leq 0.05)$.

According to Assis et al. (2019) the emergence results of seedlings in sand substrate may be considerably lower than those obtained in the laboratory germination test because, unlike the emergence test, which is conducted under sometimes unfavorable conditions. In the test of germination, the conditions of humidity, temperature, and substrate are adequate and allow expression of the maximum production potential of normal seedlings. Franco et al. (2013), concluded that the application of diquat on the common bean did not affect the seedling emergence rate index.

The use of paraquat, diquat, and the mixtures paraquat + diquat and paraquat + diuron, for soybean seed production, did not present significant changes in physiological potential (Daltro et al., 2010). The control treatment, without the use of herbicides, provided soybean seeds with a higher IVE when compared to those undergoing the application (Kappes et al., 2009).

Assis et al. (2019) verified a negative effect of ripening herbicides on cowpea plants' rate of emergence in relation to the control treatment. However, Kappes et al. (2012) observed that when 200 and $600 \mathrm{~g} \mathrm{ha}^{-1}$ of paraquat were applied to beans at 30, 35, and 40 days after 
flowering, it favored rapid seed emergence.

In a study conducted by Marchiori et al. (2002), with the objective of evaluating the effect of application of maturing herbicides on productivity and the physiological and sanitary quality of canola seeds, they concluded that the application of the herbicides ammonium glufosinate, carfentrazone-ethyl, paraquat, and diquat did not affect IVE.

In relation to the incidence of pathogens in canola seeds, fungi Fusarium spp. (Table 5) and Penicillium spp. (Table 6) were present in both seasons and treatments used. In general, it was noticed that there was an increase in the incidence of the mentioned fungi at the second time of herbicide application.

Table 5. Incidence of Fusarium spp. (\%) in Hyola 50 hybrid canola seeds as a function of treatments and maturation times

\begin{tabular}{cccc}
\hline \multirow{2}{*}{ Treatments } & Dose & \multicolumn{2}{c}{ Time of application } \\
\cline { 3 - 4 } & $\left(\mathrm{g} \mathrm{ha}^{-1} \mathrm{de} \mathrm{i.a}\right.$ or e.a $)$ & $\mathrm{G} 3$ & $\mathrm{G} 4$ \\
\hline Control & --- & $31,00 \mathrm{cB}^{1}$ & $75,00 \mathrm{bA}$ \\
Ammonium Glufosinate & 400 & 27,00 & $51,00 \mathrm{dA}$ \\
Paraquat & & $\mathrm{cdB}$ & \\
Glyphosate & 400 & $63,50 \mathrm{aB}$ & $75,00 \mathrm{bA}$ \\
Diquat & 1440 & $51,00 \mathrm{bB}$ & $84,00 \mathrm{aA}$ \\
Saflufenacil & 400 & $51,00 \mathrm{bA}$ & $49,00 \mathrm{dA}$ \\
2,4-D & 49 & $31,50 \mathrm{cB}$ & $62,00 \mathrm{cA}$ \\
& 806 & 24,50 & $71,75 \mathrm{bA}$ \\
Paraquat+diuron & $400+200$ & $25,50 \mathrm{~dB}$ & $46,50 \mathrm{dA}$ \\
Testemunha adicional & --- & $20,00 \mathrm{eA}$ & $10,75 \mathrm{eB}$ \\
\hline Average overall & --- & & 47,22 \\
CV $(\%)$ & --- & & 4,34 \\
\hline
\end{tabular}

${ }^{1}$ Means followed by the same lowercase letter in the column and upper case in the row do not differ significantly from each other by the Tukey test $(\mathrm{p} \leq 0.05)$.

It was observed that in relation to the incidence of Fusarium spp. the treatments that caused the highest indices of this pathogen were paraquat, glyphosate, and diquat in the first season of application and glyphosate, paraquat, and 2,4-D in the second season, besides the control.

In both application periods (G3 and G4), the additional control showed the lowest rates of pathogens infecting the seeds. When comparing the two seasons, it was observed that a lower incidence of Fusarium occurred when applying treatments in the G3 season, except for the additional control. According to these results, it was observed that the more hasten the application of the herbicides in the plants, the lower the incidence of fungi, generally because the pathogen penetrates the flower, and therefore, infection was higher in the second application period (G4). 
According to Reis and Casa, (2007) Fusarium spp. attacks all winter crops, being frequent in regions where there are prolonged periods of rainfall (more than 48 hours), and average temperatures during the rainy season above $20{ }^{\circ} \mathrm{C}$ after flowering. According to the meteorological data (Inmet, 2018), during the period of canola cultivation in the 2017 harvest, the ideal conditions for the occurrence of this pathogen, frosts and intense rains were combined with temperature changes. Infections caused by Fusarium spp. can affect both the physical and physiological aspects of seeds, including their size, weight, composition, and quality (Mertz, 2009).

Table 6. Incidence of Penicillium spp. (\%) in Hyola 50 hybrid canola seeds as a function of treatments and maturation times

\begin{tabular}{cccc}
\hline \multirow{2}{*}{ Treatments } & Dose & \multicolumn{2}{c}{ Time of application } \\
\cline { 3 - 4 } & $\left(\mathrm{g} \mathrm{ha}^{-1}\right.$ de i.a or e.a $)$ & $\mathrm{G} 3$ & $\mathrm{G} 4$ \\
\hline Control & --- & $45,00 \mathrm{aA}^{1}$ & $26,00 \mathrm{bcB}$ \\
Ammonium Glufosinate & 400 & $9,25 \mathrm{eA}$ & $8,50 \mathrm{eA}$ \\
Paraquat & 400 & $5,00 \mathrm{fB}$ & $36,75 \mathrm{aA}$ \\
Glyphosate & 1440 & $11,50 \mathrm{eB}$ & $22,75 \mathrm{cA}$ \\
Diquat & 400 & $9,00 \mathrm{eB}$ & $13,00 \mathrm{dA}$ \\
Saflufenacil & 49 & $20,00 \mathrm{cB}$ & $28,75 \mathrm{bA}$ \\
2,4-D & 806 & $16,00 \mathrm{dA}$ & $5,00 \mathrm{eB}$ \\
Paraquat+diuron & $400+200$ & $3,25 \mathrm{fB}$ & $27,00 \mathrm{bA}$ \\
Testemunha adicional & --- & $24,00 \mathrm{bB}$ & $27,75 \mathrm{bA}$ \\
\hline Average overall & --- & \multicolumn{2}{c}{9,24} \\
CV $(\%)$ & --- & \multicolumn{2}{c}{} \\
\hline
\end{tabular}

${ }^{1}$ Means followed by the same lowercase letter in the column and upper case in the row do not differ significantly from each other by the Tukey test $(\mathrm{p} \leq 0.05)$.

The fungus genotypes that infected soybean seeds after maturation of the plants with paraquat, diquat, and paraquat + diquat were Phomopsis spp., Fusarium spp., and Penicillium spp. in all herbicide application times (Lacerda et al., 2005). In a study by Cechinel (2014), the application of maturing herbicides in the preharvesting of wheat seeds did not affect the incidence of Fusarium graminearum, regardless of the dose and the time applied.

Silva et al. (2008), when evaluating the physiological and sanitary quality of bean seeds, found evidence of the incidence of Fusarium spp. in eight of the nine cultivars tested. According to the authors, this is a worrying finding since this pathogen has the capacity to survive in soil and be disseminated through contaminated and/or infested seeds.

The time of application of herbicides at maturation has an effect on the potential for fungal infection, and this potential increases when applied before the physiological maturity of the seeds (Fonseca, 1984). According to Smiderle and Dias, (2011) the presence of fungi in the seed coat is the main factor for low germination levels when evaluated under laboratory conditions. 
According to the incidence of Penicillium spp., it was observed that the control, at the time G3, stood out compared to the other treatments, presenting the highest infection rates of this fungus in canola seeds (Table 6). In the second season, the herbicide paraquat showed the highest incidence. When applying the mixture of paraquat + diuron and paraquat, in the first season of application, the lowest incidence of Penicillium spp. occurred. In the second period, the use of ammonium glufosinate and 2,4-D showed the lowest rates.

Treatments involving the control and 2,4-D were those that presented the lowest rates of Penicillium spp. when they were used in G4, the others were larger than those applied in G3. This can be explained by the fact that this pathogen affects the seed at the end of the crop cycle, that is, when it is entering physiological maturity, demonstrating that the earlier the application of herbicides, the lower the incidence of fungi.

The application of paraquat and paraquat + diquat had a positive effect on the sanitary quality of bean seeds, evidencing a low effect of fungi attacking the seeds (Domingos et al., 2001). However, Lacerda et al. (2003) observed lower rates of Penicillium spp. in the absence of herbicide application compared to soybean seeds that received treatment.

The use of saflufenacil as a preharvest breeder of azuki bean seeds did not affect the incidence of Penicillium spp. infecting the seeds (Tavares et al., 2015). This pathogen is considered a storage fungus, and in addition to deteriorating the seeds, can also produce mycotoxins that are toxic to humans, animals, and plants (Riverberi et al., 2010).

The presence of the genus Penicillium spp. is indicative of the deterioration of seeds, both cereals and oilseeds, promoting embryo damage, discoloration, nutritional changes, and loss of dry mass (Miller, 1995). The presence of fungi in the seeds is indeed worrying, considering the damage that can be caused by them. It is also worth mentioning that fungi associated with seeds transmit diseases to the aerial and root parts of the plant that cause losses in productivity, decreases in the physiological quality of seeds, and seedling death (Torres and Bringel, 2005).

Regardless of the maturation herbicides used in this study, the time of application that presented the highest results in all evaluated variables and a higher incidence of pathogens was G4, that is, phase in which the canola plants are entering the physiological maturation and ending their cycle.

It can be observed that the increase in the incidence of fungi in the seeds in the G4 season may be related to the results observed in the variable electrical conductivity (Table 3), where it was found that the applied herbicides impaired the integrity of the seed membranes and could have facilitated the entry of pathogens.

It is possible to carry out the application of maturing herbicides in the canola crop, and the most appropriate time corresponds to eight days before the normal harvest period (Silva et al., 2011). Knowledge of the appropriate season for the application of herbicides aiming at the anticipation of the harvest is of fundamental importance to obtaining a maximum amount of viable seeds, as well as avoiding the quality of seeds and productivity being affected (Kappes et al., 2009; Santos et al., 2004). 
On the other hand, it is necessary to know the products that will be applied to the crops, their mechanisms of action, their effects on production, germination and vigor of the seeds, as well as verifying the possibility of the presence of residues in the material (Lacerda et al., 2005). It should be noted that for the canola crop, the technical information related to the use of preharvest herbicides and the effect of these products on seed quality is scarce.

\section{Conclusion}

The additional control, harvested at the end of the crop cycle, and without herbicide application, provides the highest physical, physiological, and sanitary quality of canola seeds. The use of herbicides in the second season of application increases the one thousand seed weight and rate of emergence, but it increases the electrical conductivity and incidence of fungi. It is feasible to apply the herbicide diquat to anticipate maturation of the canola crop. The use of the 2,4-D herbicide for canola maturation adversely affects the physical and physiological quality of the seeds. There is the possibility of the use of maturing herbicides in the canola crop and the most appropriate moment for their use is in the G4 season. Applications prior to the established period bring losses to seed quality.

\section{References}

Assis, M. O., Araujo, E. F., Freitas, F. C. L., Silva, L. J., \& Araujo, R. F. (2019). Pre-harvest desiccation in productivity and physiological quality of cowpea seeds. Planta Daninha, 37, e019177741. https://doi.org/10.1590/s0100-83582019370100014.

Bellé, C., Kulczynski, S. M., Basso, C. J., Edu Kaspary, T., Lamego, F. P., \& Pinto, M. A. B. (2014). Yield and quality of wheat seeds as a function of desiccation stages and herbicides. Journal of Seed Science, 36, 63-70. https://doi.org/10.1590/S2317-15372014000100008

Botelho, F. J. E., Oliveira, J. A., Von Pinho, É. V. D. R., Carvalho, E. R., Figueiredo, Í. B. D., \& Andrade, V. (2016). Qualidade de sementes de soja obtidas de diferentes cultivares submetidas à dessecação com diferentes herbicidas e épocas de aplicação. Revista Agro@ mbiente On-line, 10, 137-144. https://doi.org/10.18227/1982-8470ragro.v10i2.2760

BRASIL, Ministério da Agricultura, Pecuária e Abastecimento (2009). Regras para Análise de Sementes. Secretaria da defesa agropecuária, Brasília: Mapa, 2009. 399p.

Cechinel M. H. (2014) Dessecação química em pré-colheita do trigo. 107 f. Dissertação (mestrado) - Universidade do Estado de Santa Catarina, Centro de Ciências Agroveterinárias, Programa de Pós-Graduação em Produção Vegetal.

Coelho, C. M. M., Coimbra, J. L. M., Souza, C. A. D., Bogo, A., \& Guidolin, A. F. (2007). Diversidade genética em acessos de feijão (Phaseolus vulgaris L.). Ciência Rural, 37, 1241-1247. https://doi.org/10.1590/S0103-84782007000500004

Coelho, C. M. M., Souza, C. A., Zilio, M., \& Michels, A. F. (2012). Ação de dessecante na pré-colheita sobre a produtividade e a qualidade fisiológica de sementes crioulas de feijoeiro. Semina: Ciências Agrárias, 33, 2973-2980. https://doi.org/10.5433/1679-0359.2012v33n6Sup11p2973 
Cordeiro, L. A. M., Reis, M. S., Alvarenga, E. M. A cultura da canola. (Cadernos didáticos, 60). Viçosa: UFV, 1999.

Daltro, E. M. F., Albuquerque, M. C. D. F., França Neto, J. D. B., Guimarães, S. C., Gazziero, D. L. P., \& Henning, A. A. (2010). Aplicação de dessecantes em pré-colheita: efeito na qualidade fisiológica de sementes de soja. Revista Brasileira de Sementes, 32, 111-122. https://doi.org/10.1590/S0101-31222010000100013

Domingos, M., da Silva, A. A., da Silva, R. F., da Silva, J. F., \& Cardoso, A. A. (2001). Efeitos de dessecantes, da época de colheita, do enleiramento e da chuva simulada no rendimento e na qualidade fisiológica das sementes de feijão. Revista Ceres, 48, 365-380. http://www.ceres.ufv.br/ojs/index.php/ceres/article/view/2697

Fonseca, N. (1984). Influência da aplicação de paraquat sobre a produção e a qualidade da semente de soja (Glycine $\max$ (L.) Merrill). 48f. Dissertação (Mestrado em Agronomia)-Universidade Federal de Viçosa.

Franco, M. H. R., Nery, M. C., França, A. C., Oliveira, M. C., Franco, G. N., \& Lemos, V. T. (2013). Produção e qualidade fisiológica de semente de feijão após aplicação do herbicida Diquat. Semina: Ciências Agrárias, $\quad 4, \quad$ 1707-1713. https://doi.org/10.5433/1679-0359.2013v34n4p1707

Gonzales, J. L. S., Paula, R. C. D., \& Valeri, S. V. (2009). Teste de condutividade elétrica em sementes de Albizia hassleri (Chodat) Burkart. Fabaceae-Mimosoideae. Revista Árvore, 33, 625-634. https://doi.org/10.1590/S0100-67622009000400005

Henning, A. A. (2015). Guia prático para identificação de fungos mais frequentes em sementes de soja. Brasília; Embrapa, 2015. 33p.

Kamikoga, Á. T. M., Kamikoga, M. K., Terasawa, J. M., Romanek, C., \& Penkal, K. F. (2009). Efeito de diferentes épocas de aplicação de três herbicidas dessecantes na produção e qualidade fisiológica de sementes de feijão. Publicatio UEPG: Ciências Exatas e da Terra, Agrárias e Engenharias, 15, 53-61. https://doi.org/10.5212/Publ.Exatas.v.15i1.053061

Kappes, C., Arf, O., Ferreira, J. P., Portugal, J. R., Alcalde, A. M., Arf, M. V., \& Vilela, R. G. (2012). Qualidade fisiológica de sementes e crescimento de plântulas de feijoeiro, em função de aplicações de paraquat em pré-colheita. Pesquisa Agropecuária Tropical, 42, 9-18. https://doi.org/10.1590/S1983-40632012000100002

Kappes, C., de Carvalho, M. A. C., \& Yamashita, O. M. (2009). Potencial fisiológico de sementes de soja dessecadas com diquat e paraquat. Scientia Agraria, 10, 1-6. https://doi.org/10.5380/rsa.v10i1.12520

Lacerda, A. L. D. S., Lazarini, E., Sá, M. E. D., \& Valério Filho, W. V. (2003). Armazenamento de sementes de soja dessecadas e avaliação da qualidade fisiológica, bioquímica e sanitária. Revista Brasileira de Sementes, 25, 97-105. https://doi.org/10.1590/S0101-31222003000400014

Lacerda, A. L. D. S., Lazarini, E., Sá, M. E. D., \& Valério Filho, W. V. (2005). Efeitos da 
dessecação de plantas de soja no potencial fisiológico e sanitário das sementes. Bragantia, 64, 447-457. https://doi.org/10.1590/S0006-87052005000300015

Lamego, F. P., Gallon, M., Basso, C. J., Kulczynski, S. M., Ruchel, Q., Kaspary, T. E., \& Santi, A. L. (2013). Dessecação pré-colheita e efeitos sobre a produtividade e qualidade fisiológica de sementes de soja. Planta Daninha, 31, 929-938. https://doi.org/10.1590/S0100-83582013000400019.

Maguire J. D. (1962). Speeds of germination-aid selection and evaluation for seedling emergence and vigor. Crop Science, 176-177. https://doi.org/10.2135/cropsci1962.0011183X000200020033x

Marcandalli, L. H., Lazarini, E., \& Malaspina, I. C. (2011). Épocas de aplicação de dessecantes na cultura da soja: qualidade fisiológica de sementes. Revista Brasileira de Sementes, 33, 241-250. https://doi.org/10.1590/S0101-31222011000200006

Marchiori Jr, O., Inoue, M. H., Braccini, A. L., Oliveira Jr, R. S., Avila, M. R., Lawder, M., \& Constantin, J. (2002). Qualidade e produtividade de sementes de canola (Brassica napus) após aplicação de dessecantes em pré-colheita. Planta Daninha, 20, 253-261. https://doi.org/10.1590/S0100-83582002000200012

Mertz, L. M., Henning, F. A., \& Zimmer, P. D. (2009). Bioprotetores e fungicidas químicos no tratamento de sementes de soja. Ciência Rural, 39, 13-18. https://doi.org/10.1590/S0103-84782009000100003

Miller J.D. (1995). Fungi and mycotoxins in grain: implications for stored product research. Journal of Stored Products Research, 31, 1-16. https://doi.org/10.1016/0022-474X(94)00039-V

Neves R. (2005). Potencial alelopático da cultura da canola (Brassica napus L. var. oleifera) na supressão de picão-preto (Bidens sp.) e soja. 77p. Dissertação (Mestrado em Agronomia)-Faculdade de Agronomia e Medicina Veterinária, Universidade de Passo Fundo, curso de pós-graduação em Agronomia.

Pelúzio, J. M., Ramo, L. N., Fidelis, R. R., Afférri, F. S., de Castro Neto, M. D., \& Correia, M. A. R. (2008). Influência da dessecação química e retardamento de colheita na qualidade fisiológica de sementes de soja no sul do estado do Tocantins. Bioscience Journal, 24, 77-82. http://www.seer.ufu.br/index.php/biosciencejournal/article/view/6996

Pinto, M. A. B., Basso, C. J., Kulczynski, S. M., \& Bellé, C. (2014). Productivity and physiological quality of seeds with burn down herbicides at the pre harvest of bean crops. Journal of Seed Science, 36, 384-391. https://doi.org/10.1590/2317-1545v36n4997

Reis E. M., \& Casa R. T. (2007). Doenças dos cereais de inverno: Diagnose, epidemiologia e controle. 2.ed. rev. atual. Lages: Graphel, 176p.

Reverberi, M., Ricelli, A., Zjalic, S., Fabbri, A. A., \& Fanelli, C. (2010). Natural functions of mycotoxins and control of their biosynthesis in fungi. Applied microbiology and biotechnology, 87, 899-911. https://doi.org/10.1007 / s00253-010-2657-5 
ROLAS, Rede Oficial de Laboratórios de Análise de Solo e de Tecido Vegetal dos Estados do Rio Grande do Sul e de Santa Catarina. Sociedade Brasileira de Ciência do Solo (2016). Comissão de Química e Fertilidade do Solo: Porto Alegre, 2016. 400p.

Santos, J. B., Ferreira, E. A., Santos, E. A., Silva, A. A., Silva, F. M., \& Ferreira, L. R. (2004). Qualidade de sementes de feijão (Phaseolus vulgaris) após aplicação do carfentrazone-ethyl em pré-colheita. Planta Daninha, 633-639. https://doi.org/10.1590/S0100-83582004000400019.

Silva, G. C., Gomes, D. P., Kronka, A. Z., \& Moraes, M. H. (2008). Qualidade fisiológica e sanitária de sementes de feijoeiro (Phaseolus vulgaris L.) provenientes do estado de Goiás. Semina: Ciências Agrárias, 29, 29-34. https://doi.org/10.5433/1679-0359.2008v29n1p29

Silva, J. A., da Motta, M. B., Winch, J. A., Crestani, M., Fernandes, S. B., \& Berto, J. L., Zambonato, F. (2011). Dessecação em pré-colheita como estratégia de manejo na redução de perdas por fatores de ambiente em canola. Current Agricultural Science and Technology, 17, 15-24. https://periodicos.ufpel.edu.br/ojs2/index.php/CAST/article/viewFile/2027/1864

Smiderle O. J., \& Dias C. T. S. (2011). Época de colheita e armazenamento de sementes de arroz produzidas no cerrado de Roraima. Revista Agroambiente, 5, 18-23. https://www.alice.cnptia.embrapa.br/bitstream/doc/904305/1/426.pdf

Tavares, C. J., Araújo, A. C., Jakelaitis, A., Resende, O., Sales, J. D. F., \& Freitas, M. A. (2015). Qualidade de sementes de feijão-azuki dessecadas com saflufenacil e submetidas ao armazenamento. Revista Brasileira de Engenharia Agrícola e Ambiental, 19, 1197-1202. https://doi.org/10.1590/1807-1929/agriambi.v19n12p1197-1202.

Tomm, G. O., Wiethölter, S., \& Dalmago, G. A., dos Santos, H. P. (2009). Tecnologia para produção de canola no Rio Grande do Sul. Passo Fundo: Embrapa Trigo, 2009. 88p.

Torres S. B., \& Bringel J. M. M. (2005). Avaliação da qualidade sanitária e fisiológica de sementes de feijão macassar. Revista Caatinga, 18, 88-92. https://www.researchgate.net/publication/237502880_Avaliacao_da_qualidade_sanitaria_e_fi siologica_de_sementes_de_feijao-macassar

\section{Copyright Disclaimer}

Copyright for this article is retained by the author(s), with first publication rights granted to the journal.

This is an open-access article distributed under the terms and conditions of the Creative Commons Attribution license (http://creativecommons.org/licenses/by/4.0/). 